\title{
Sustainable Development and Planning for Environmental Protection in Offshore Oil Drilling and Production Industry
}

\author{
O Aboul Dahab* \\ Faculty of science, Department of Oceanography, University of Alexandria, Egypt
}

Submission: September 1, 2019; Published: October 09, 2019

Corresponding author: O Aboul Dahab, Faculty of science, Department of Oceanography, University of Alexandria, Egypt

\begin{abstract}
This work summarizes the types and environmental negative effects of offshore oil drilling and production wastes. These wastes include production chemicals, drilling fluids, production and formation waters, heavy metals, salt, petroleum hydrocarbons, air pollutants, nuclear radiation in addition to the acoustic impacts. Damage to the coastal environment has three potential costs to present and future human welfare. Human health may be harmed. Economic productivity may be reduced. The pleasure or satisfaction obtained from an unspoiled environment, often referred to as its "amenity" value may be lost. The present work also discusses the importance of developing comprehensive environmental protection plans and measures to optimize the use of offshore oil resources as a tool for achieving sustainable development in this highly important economic sector. Environmental protection plans for offshore oil drilling and production industry may include environmental audits, waste management plans, waste management actions, contingency plans and employee training. Environmental protection measures which can be considered in offshore oil drilling and production are drilling operations, management requirements, planning and phasing, site visits, environmental preparedness, restoration and abandonment completion
\end{abstract}

\section{Introduction}

Sustainable development is development that lasts. The general principle of sustainable development adopted by the World Commission of Environment and Development that current generations should "meet their needs without compromising the ability of future generations to meet their own needs"- has become widely accepted. The protection of the environment is an essential part of development. Without adequate environmental protection, development is undermined; without development, resources will be inadequate for needed investments, and environmental protection will fail [1]. The petroleum exploration, production and the associated industry have the potential to impact the environment [2]. Therefore, comprehensive environmental protection plans, including waste management and contingency plans, are needed to optimize the use of offshore oil resources as a tool for achieving sustainable development [3].

\section{Objectives}

The present work aims at demonstrating i. the types and effects of offshore oil drilling and production industry, ii. The importance of developing comprehensive environmental protection plans, iii.
Measures to optimize the use of offshore oil resources to achieve sustainable development, and iv. Effects of offshore platforms and rigs.

\section{Methodology}

This work is prepared using descriptive approach in addition to the writer knowledge and experience in the area of marine pollution and its control and also in view of the information gained during several site visits to rigs and platforms belonging to different oil companies working in the Arabian Gulf area during the period from 2002 to 2010 .

\section{Results and Discussion}

Offshore oil drilling and production industry wastes include petroleum hydrocarbons, salt, heavy metals, production chemicals, drilling fluids, produced water, nuclear radiation in addition to air pollutants and acoustic impacts [4] . These wastes have three potential costs to present to future human welfare. Human health may be harmed. Economic productivity may be reduced, and the pleasure or satisfaction obtained from an unspoiled environment, often referred to as its "amenity" value, may be lost. Environmental protection measures which can be 
considered in offshore oil drilling and production industry are i. management requirements, ii. planning and phasing, iii. site visits, iv. environmental preparedness (legislation, social aspects and consultation, training, drilling contracts, drill site, special areas, oil spills, and pre-drilling activities), v. drilling operations (rig components and equipment, drilling fluids, chemicals, waste management, well testing and awareness), vi. Well abandonment and completion, vii. Restoration (well and cellar areas, drilling waste pits, site size protection, spill rates and platforms and rigs sites [5].

The proposed steps for planning for environmental protection in offshore oil drilling and production industry start with executing an environmental audit to identify all the waste streams at a site and to determine whether those waste streams are being handled, stored, transported, treated and disposed. It also indicates how records to be kept. The second step is to prepare contingency plans to minimize the impacts of accidental releases of materials and should include relevant emergency responses. Since operations, regulations and technology are constantly changing, environmental audits should be conducted periodically, and associated waste management and contingency plans should be updated as needed. Environmental protection plans should be prepared with the guidance of people who are knowledgeable in the technical and the operational aspects of the system together with the regulatory and waste disposal experts. These plans need the visible support of top management and require the active participation of field personnel, both in developing and implementing them.

Environmental management encompasses a variety of approaches for dealing with waste, strategies that reduce or eliminate wastes before they are created are preferable to those that deal with treating or disposing wastes that are already generated. The proposed hierarchy which can be used to prioritize the waste management includes waste i. prevention (The best waste reduction strategy is the one that keeps waste from being formed in the first place.), ii. recycling and reuse (If waste generation is unavoidable in a process, then strategies that minimize the waste to the greatest extent possible should be pursued, such as recycling and reuse.), iii. treatment (when wastes cannot be prevented or minimized through reuse or recycling, strategies to reduce their volume or toxicity through treatment can be pursued.), and iv. disposal (the last strategy to consider alternative disposal methods. Proper waste disposal is an essential component of an overall environmental management program; however, it is the least effective technique.) $[6,7]$.
The proposed steps for developing contingency plans can be summarized as follows: step 1 . Identify potential emergencies and complications, step 2. Identify risks and consequences on human life, wildlife and the environment, step 3. Identify resources and capabilities such as personnel, equipment, supplies and funds, step 4. Determine and define roles and responsibilities, step 5. Determine response actions and decision-making priorities, step 6. Write, approve and implement the plan (easyto-understand language, user-friendly and allow for updates). The actual environmental impact of the offshore oil exploration and production activities is very low when properly managed. In some cases, the presence of offshore platforms and rigs can be beneficial. The subsea structure (jacket) provides a substrate for marine flora to grow. This flora attracts fauna including fish of different types and sizes. This high fauna occurrence provides enhanced commercial and recreational fishing opportunities.

When an offshore oil drilling or production process is abandoned, the platform must be removed. The least expensive and safest method for platform removal has been to use explosives. This method can be lethal to the nearby marine life (any endangered species in the area must be monitored and removed before detonation. Other methods include acid cutting, embattlement through liquid nitrogen freezing, water lasting, fuel cutting torches and mechanical cutters. These methods may result in a great safety hazards to the personnel implementing them.

\section{References}

1. Aboul Dahab O, Shabaan N (2017) Environmental protection and management in coastal and maritime industries. Oceanography and fisheries open access journal 5(3).

2. Torgeir B, Steinar S (2013) Environmental impacts of produced water and drilling waste discharged from the Norwegian offshore petroleum industry. Marine environmental research 92: 154-169.

3. John C Reis (1996) Environmental control in petroleum engineering. In: Elsevier Inc book, Netherlands, Pp. 400

4. Sharif AS, Nagalak Shmi NVR, Stigowri RS, Vanth G, Uma SK (2017) Drilling waste management and control the effects. Journal of Advanced Chemical Engineering 7:1.

5. Aboul Dahab 0 (2013) Environmental measures in the field of offshore oil industry. OMICs Group International Conference on oceanography and natural disasters, Orlando, USA.

6. Onwukwe SI, Nwakaudu MS (2012) Drilling wastes generation and management approach. International Journal of environmental science and development 3(3).

7. API (2000) Overview of exploration and production waste volumes and waste management practices in the united states, Prepared by ICF consulting for the American Petroleum Institute. 


\section{Your next submission with Juniper Publishers will reach you the below assets}

- Quality Editorial service

- Swift Peer Review

- Reprints availability

- E-prints Service

- Manuscript Podcast for convenient understanding

- Global attainment for your research

- Manuscript accessibility in different formats ( Pdf, E-pub, Full Text, Audio)

- Unceasing customer service

Track the below URL for one-step submission https://juniperpublishers.com/online-submission.php 